\title{
INFLUENCE OF CONTACT PRESSURE AND SLIDING SPEED ON THE TEMPERATURE AND COEFFICIENT OF FRICTION IN SLIDING CONTACT BETWEEN TWO PET SAMPLES
}

\author{
Zoran Domitran, Dragan Žeželj, Branko Katana
}

Original scientific paper

The use of polymeric materials has been growing steadily. A more extensive use of polymers as bearing materials will be made possible by a better knowledge of the properties of particular materials and their compatibility in a particular application. Poly(ethylene terephthalate) (PET) with the addition of Polytetrafluorethylene (PTFE) shows potential for being used as a material for machine parts rotating at lower loads due to its good ratio between manufacturing costs and mechanical properties. The use of PET in a PET/PET combination has been tested in three working points, with a lubricant applied once in each run and with three different values of sliding speed and of load. The change in temperature which occurs in the vicinity of the outlet zone of the contact at the end of the sliding path after 9 hour operation is presented. The applied method and temperature measurement are explained. The distribution of obtained maximum and average temperatures in the load range $9 \div 18 \mathrm{MPa}$ and the sliding speed range $0,8 \div 2 \mathrm{~m} / \mathrm{s}$ is shown for single working points. In addition, the effects of lubricant application on the increase in the magnitude of the load carrying capacity and on the decrease in the value of friction coefficient are shown in comparison with the reference values of temperature and friction coefficient in the dry contact operation.

Keywords: flash temperature; friction; load; PET; sliding

Utjecaj kontaktnog pritiska i brzine klizanja na temperaturu i faktor trenja u kontaktu s uzorcima od PET-a

Izvorni znanstveni članak Upotreba polimernih materijala u stalnom je porastu, područje primjene polimera kao ležajnog materijala povećat će se boljim poznavanjem karakteristika pojedinih materijala te njihove kompatibilnosti u određenim primjenama. Primjena polietilen tereftalata (PET) s dodatkom politetraflouretilena (PTFE) zbog omjera proizvodnih troškova i mehaničkih svojstava pokazuje potencijal u primjeni kod strojnih dijelova u rotaciji pri nižem opterećenju. Primjena PET-a u kombinaciji PET/PET ispitana je u tri radne točke uz jednokratnu primjenu maziva kod tri različita iznosa obodnih brzina i opterećenja. Prikazana je promjena temperatura koja se javlja u području neposredno nakon izlaza iz zahvata ispitnih uzoraka tijekom rada za ukupni prijeđeni put u trajanju od $9 \mathrm{~h}$, uz obrazloženje metode mjerenja temperature. Za pojedine radne točke prikazana je raspodjela dobivenih maksimalnih i srednjih temperatura prema opterećenju od 9 do $18 \mathrm{MPa}$ te za područje obodnih brzina od 0,8 do $2 \mathrm{~m} / \mathrm{s}$. Prikazan je utjecaj maziva na povećanje opteretivosti i smanjenje faktora trenja primjenom maziva uz referentne vrijednosti temperatura i faktora trenja pri radu na suho.

Ključne riječi: blic temperatura; klizanja; opterećenje; PET; trenje

\section{Introduction}

Polymeric materials are widely used in industry as they contribute to a reduction in production costs and have relatively good mechanical and tribological properties. Polymers are preferred in the applications where traditional materials cannot satisfy specific operating conditions, or in the applications in which the use of any other material is impossible due to special operating conditions and environments. If two materials are in contact and in relative motion, the materials begin to show wear. Some polymeric materials show good results in the applications where resistance to wear influences the life of the product and the proper operation of a system and in particular operating conditions such as insufficient lubrication, the lack or inability of lubrication, aggressive medium, etc.

According to J. K. Lanchester [1, 2], a polymer used for plain bearings should have the following properties:

- low friction and wear

- high chemical resistance

- good thermal and dimensional stability

- small change in strength under the influence of operating temperature

- low absorption of working fluids or some other medium in contact with the plain bearing.

It is generally true about polymers that the use of lubricants results in reduced wear, which consequently results in a longer service life. Tests carried out on samples in a polymer/metal combination $[1 \div 3]$ indicate that the use of lubricants reduces friction but also has an effect on the load carrying capacity. Bin Bin Jia [3] tested the load carrying capacity of the PA66 engineering polymer with the use of lubricants and without it. A comparative analysis showed a far greater influence of operating pressure and rotational speed on the friction and wear in the samples tested without the use of a lubricant than in those tested with the use of oil. In addition, the results suggested that oil diffusion into the material could have some influence if the material is PA66. Using various types of oils it is possible to exert influence on the friction coefficient and the rate of wear. Audris Zunda [4] confirms that samples made of Polyamide (PA) and of Polyoxymethylene (POM) exhibit sensitivity to absorption of some types of oils, which affects wear resistance. Samples made of PTFE exhibited the best wear resistance. Water can also be used as a lubricant in bearings made of polymers. Nguyen [5] carried out experimental research to determine how the use of several types of water as a lubricant affects the friction coefficient of samples made of PET, Ultrahigh Molecular Weight Polyethylene (PE-UHMW). He concluded that the use of water with cheap materials offers a wide range of applications due to their insensitivity to water absorption. $\mathrm{He}$ also pointed out that PET samples exhibited lower friction coefficients after long-term testing, while no changes were observed with PE-UHMW samples. Sukuruman [5, 6] and his collaborators extended their research by using water as a lubricant with some other polymeric materials. The research resulted in a list of wear mechanisms for particular polymers and a 
conclusion that a positive effect of water on friction reduction was confirmed. The research presented in $[1 \div 6]$ was carried out in the systems with applied lubrication or in dry operation.

Another group of authors led by B. J. Briscoe and S. K. Sinha [8] tried to prove that there is a connection between different contacts of samples and material parameters and to describe the wear pattern of polymers. They divided the parameters affecting wear into three groups:

1) Conditions of sliding friction such as the surface quality $(\mathrm{Ra})$ and the kinematics of the tested body.

2) Mechanical properties of the polymer and their dependence on temperature and environment.

3) This group of parameters depends on the first two groups and includes the interrelation of three bodies.

In addition, the main problem of wear prediction, which includes still undefined operating conditions and mechanical properties of a third body, is defined.

The temperature impact on polymeric materials in contact was investigated by J. W. Mens [9] and his associates who tested 18 types of polymers in dry operation and in water. They performed measurements by using thermocouples installed in the metallic sample and noted differences in temperature in the polymer-metal contact zone among the tested polymers. As a result, engineering polymers were classified as a group in which higher temperatures are obtained in contact, which was explained by the composition of these polymers mostly having crystal structure $[9,10]$ in which transition temperatures $T_{g}$ limit the engineering application of polymers. It was noted that there was a significant drop in temperature when tests were carried out in water, which can be accounted by the fact that heat is carried away from the measuring point. Gruender [12] investigated the influence of operating parameters on high performance polymers in dry operation by using thermocouples installed in the metallic sample. The melting point was taken as a boundary condition for satisfying the service life condition. It was concluded that by increasing the P-V (Pressure - Velocity) values, the temperature in contact rises. Here, a possible influence of the manufacturing technology of the sample should also be noted. The final conclusion was that seizure occurs at temperatures below the melting point of polymers. Brostow [13] and Lancaster $[1,2]$ pointed out the fact that temperature has a strong influence on mechanical properties of polymers as the main obstacle to their wider application, together with low conductivity tendency of these materials, their tendency to creep, viscoelasticity [14], and a strong influence of environment and operating parameters. Opalić [15] and his collaborators tried to determine which operating parameters influence the coefficient of friction in the condition of lubricating the polymeric materials in contact with bronze. They concluded that besides the influence of the rotational speed and load, part of the heat generated in contact changes the temperature of lubricating oil, which significantly influences the value of the coefficient of friction, and thus leads to a change in wear. Tevrüz [16] noted that it is possible to reduce the impact of rotational speed and pressure in bearings made of PTFE with $35 \%$ carbon operating at low and medium speeds by cooling (which is confirmed by research conducted in [15]). In this condition, stable wear occurs after 6-8 hours of operation and a stable coefficient of friction after $20 \div 25$ hours. An increase in temperature increases the coefficient of friction in a dry test, while a drop in pressure entails a decreased value of the coefficient of friction.

The temperature in the contact zone is a key factor which influences the quality of operation of bearings made of polymeric materials $[7,8,11,13,15,16]$. Determination of the accurate value of flash temperature plays a major role [1] in the overall temperature that influences the operation of a polymer bearing. Theoretical formulations in $[1,17]$ do not provide sufficiently precise descriptions of flash temperature $T_{\mathrm{f}}$ determination in specific operating conditions, while experimental research has certain technical limitations in the measurement of the temperature in the contact zone. The group of authors in $[8,11,13,16]$ uses a standard way of temperature determination by means of thermocouples installed in the metallic sample. The problem related to this type of temperature measurement is in the measuring system inertia which results in reduced accuracy of measurement since the flash temperature $T_{\mathrm{f}}$ is localized and lasts for a very short period. Inaccuracy in measurement also occurs in the case when the heat transfer coefficient of the sample operating in oil is measured. The other group of authors $[17,18,19,20]$ tries to solve the problem of measurement inaccuracy by contactless measurement in the close vicinity of the heat source. The benefit of this method is that it can be conducted very quickly, but on the other hand, its disadvantage are the problems related to the influence of environmental and operating conditions, inaccessibility of the area and the object to be measured, and differences between the response signals of two dissimilar materials.

In this study, we will investigate the kinetic friction between two polymers with added PTFE in contact (PET/PET). Synthetic lubricant with viscosity of 15 $\mathrm{mm}^{2} / \mathrm{s}$ will be used. Diagrams of changes in temperature and coefficient of friction will be determined in the sliding speed range $0,8 \div 2,0 \mathrm{~m} / \mathrm{s}$ and the load range $60 \div$ 210 N. During operation, contactless measurements of temperature and friction coefficient will be performed in given conditions. Surface roughness will be measured before and after the testing.

\section{Materials and methods 2.1 Material selection}

The material selected for the experiment is Poly(ethylene terephthalate) (PET) alloyed with Polytetrafluoroethylene (PTFE), which has been approved by the Food and Drug Administration (FDA). Because of its mechanical and tribological characteristics PET is widely used in complex industrial processes such as textile production, food production and in pharmaceutical industry. PET is used for various types of rollers for conveyers and for slide and journal bearings, etc. Unlike some other polymers, PET does not suffer from significant changes in strength up to $80{ }^{\circ} \mathrm{C}$, but it is prone to hydrolysis if exposed to hot water (above $70{ }^{\circ} \mathrm{C}$ ). Working temperature of the material is in the range 
between $-20{ }^{\circ} \mathrm{C}$ and $110{ }^{\circ} \mathrm{C}$, with momentary rises to 170 ${ }^{\circ} \mathrm{C}$. The glass transition temperature $T_{\mathrm{g}}$ of the material is about $82{ }^{\circ} \mathrm{C}$.

Samples to be tested are discs and cubes produced by machining from commercially obtained parts available on the market. After machining, the surface roughness $R a$ is in the range between 1,22 and $1,54 \mu \mathrm{m}$.

\subsection{Lubricant selection}

Depending on working conditions and load, PET can be lubricated with low viscosity lubricants like water, or with lubricants of higher viscosity like mineral and synthetic oils. In the former case, the compatibility between the material and the lubricant should be checked regardless of the known good chemical resistance of PET.

For this testing, a commercial can pack synthetic oil is selected. According to the application range description, the selected synthetic oil is intended for the lubrication of polymer parts in bottle filling machines used in food industry and it is not intended for a continuous inflow (e.g. from reservoir or complex lubricating systems). Common characteristics of the lubricant are presented in Tab. 1.

Table 1 Characteristics of the selected oil

\begin{tabular}{|l|c|}
\hline \multicolumn{1}{|c|}{ Composition } & $\begin{array}{c}\text { Ester oil, synthetic } \\
\text { hydrocarbon oil }\end{array}$ \\
\hline Service range, ${ }^{\circ} \mathrm{C}$ & -45 to 110 \\
\hline Colour & Light yellow \\
\hline $\begin{array}{l}\text { Kinetic viscosity DIN51562 pt. 01 } \\
\text { at } 40^{\circ} \mathrm{C}, \mathrm{mm}^{2} / \mathrm{s}\end{array}$ \\
at $100^{\circ} \mathrm{C}, \mathrm{mm}^{2} / \mathrm{s}$ & 15 \\
\hline ISO VG DIN 51519 & 3,5 \\
\hline Viscosity index, DIN ISO 2909 & 15 \\
\hline Corrosion on Copper, & $\geq 120$ \\
DIN EN $2160,24 \mathrm{~h} / 100{ }^{\circ} \mathrm{C}$ & 1 at 100 \\
\hline
\end{tabular}

Prior to the main testing, a trial was conducted in order to verify whether the sliding velocity of $2 \mathrm{~m} / \mathrm{s}$ is safe from the aspect of lubricant removal from the contact. It turned out that the adhesion of the lubricant was sufficient since no lubricant removal had occurred.

\subsection{Equipment}

An adapted testing device with a rotating disc and a theoretical line contact between the disc and the plane surface is used [15]. The device (Fig. 1) consists of the actuating part, the loading part, and the measuring system. The actuating part consists of an electric motor with a frequency regulator, a measuring shaft and, at the end, a disc sample. The loading part consists of the cube sample firmly fixed in the vertically movable sample holder equipped with the force transducer, and the lever loading system. The over dimensioned shaft (not prone to deflection) carrying the disc sample and the cube sample holder are well positioned in the robust housing providing a contact which is close to the theoretical line contact between the cylindrical surface of the disc and the bottom surface of the cube. Dimensions of the disc sample are 45 $\mathrm{mm}$ in diameter and $15 \mathrm{~mm}$ in thickness while the cube sample has the sides of $35 \mathrm{~mm}$ in length.

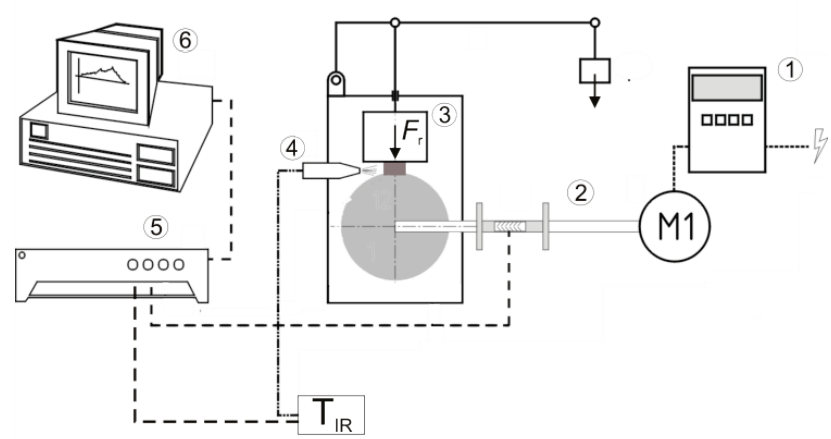

Figure 1 Schematics of the test setup

The measuring system (Fig. 1) consists of a frequency regulator (1) which provides data on the rotational speed, a torque measuring shaft (2) which is integrated in the actuating part, a force transducer (3) which is integrated in the loading part, a contactless temperature indicator (4), a measuring amplifier (5) and a computer program for data acquisition (6) installed on a personal computer.

The given load is applied to the disc sample by means of the cube sample loaded by the lever system and recorded by the force transducer. As the disc rotates, a tractive force between the samples is produced, inducing torque which is recorded by the measuring shaft. The coefficient of friction can be calculated from the measured data while the sliding velocity can be calculated from the frequency regulator data and the disc diameter.

\subsubsection{Temperature measurement}

Temperature measurement is the most delicate part of the testing [1]. The highest and the most significant temperature in the contact zone, the flash temperature $T_{\mathrm{f}}$, occurs locally in the contact area, in a short period of time, and it cannot be measured directly. In addition, the coefficient of conduction for polymer materials (e.g. for PET in the range $0,15 \div 0,4 \mathrm{~W} /(\mathrm{mK}))$ is low in general compared to that of metals (e.g. $43 \mathrm{~W} /(\mathrm{mK})$ for common carbon steel), which results in slow heat transfer. Because of the both mentioned issues, measuring of the flash temperature of polymer samples using a contact thermometer is technically challenging and the measured values are questionable. On the other hand, contactless measuring of the temperature has its own drawbacks. The first and the biggest one is that the area of the contact is not optically visible so only the temperature in the vicinity of the contact can be measured rather than the flash temperature itself. The second is that contactless temperature indicators have somewhat lower resolution compared to the contact ones. The third and the last one is that contactless measuring can be easily influenced by the environment; therefore, it is an imperative to focus the measuring beam to the point at which the temperature is being measured. The main obstacle to focusing the measuring beam properly is the oil film which, although very thin, will interfere with the measurement. Taking into consideration all of the above, as well as the geometry of the samples, the type of contact, and the testing conditions, the contactless temperature indicator intended for measuring the surface temperature of polymer parts is selected (Tab. 2). 
Table 2 Measurement specifications of the selected contactless temperature indicator

\begin{tabular}{|l|c|}
\hline Temperature range & $0{ }^{\circ} \mathrm{C}$ to $710^{\circ} \mathrm{C}$ \\
\hline Spectral range & $7,9 \mu \mathrm{m}$ \\
\hline Optical resolution $(90 \%$ energy) & $10: 1$ \\
\hline $\begin{array}{l}\text { System accuracy }(\text { at ambient } \\
\left.\text { temperature } 23 \pm 5^{\circ} \mathrm{C}\right)\end{array}$ & $\pm 1 \%$ or $\pm 1,5^{\circ} \mathrm{C}$ \\
\hline $\begin{array}{l}\text { Repeatability }(\text { at ambient } \\
\left.\text { temperature } 23 \pm 5^{\circ} \mathrm{C}\right)\end{array}$ & $\pm 0,5 \%$ or $\pm 0.5^{\circ} \mathrm{C}$ \\
\hline Temperature resolution (NETD) & $0,5 \mathrm{~K}$ \\
\hline Exposure time $(90 \%$ signal) & $150 \mathrm{~ms}$ \\
\hline Emissivity/Gain & $0,100 \div 1,100$ \\
\hline Transmissivity/Gain & $0,100 \div 1,100$ \\
\hline
\end{tabular}

The indicator is firmly attached to the housing of the testing device, in the position which provides direct optical visibility of the contact zone outlet. During the trial, the angle of the beam ( $\beta$ in Fig. 2$)$ and the vertical position of the indicator are gradually adjusted until the maximum temperature reading is reached. This value is assumed as the nearest measurable temperature close to the flash temperature $T_{\mathrm{f}}$ in the contact. For the sake of simplification, it is assumed that the temperature field spreads radially through the samples from the contact zone, as shown in Fig. 2.

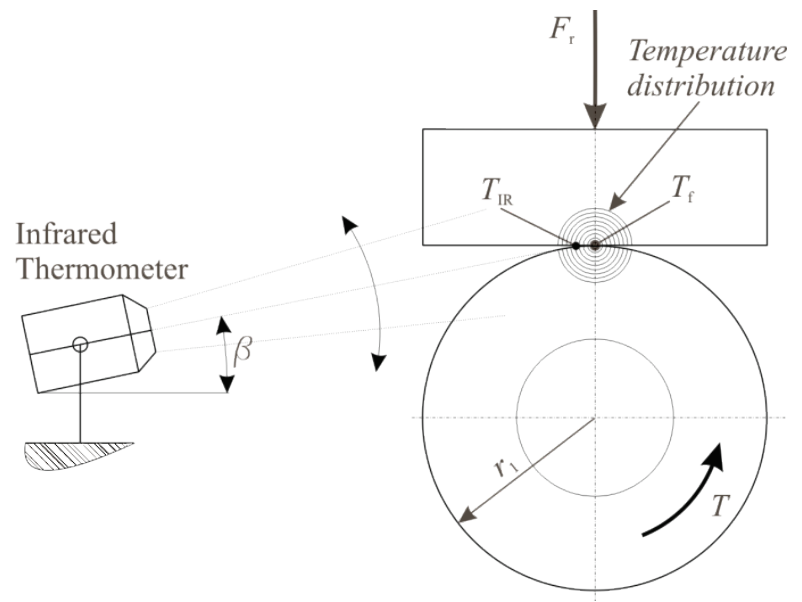

Figure 2 Contactless measuring of the temperature in the outlet zone of the contact

\section{Selection of parameters and the experiment}

In order to provide a sufficient amount of data to determine the change in the dynamic coefficient of friction, the frequency of data acquisition is set to $60 \mathrm{~Hz}$. The data acquisition for torque $T$, load and temperature, at a constant rotation frequency of the disc, is continuous. By using discrete values for the torque $T$, the traction force $F_{\text {tr }}$ for each measuring point can be calculated using expression (1), while the dynamic coefficient of friction $\mu_{\text {din }}$ can be determined for each measuring point from the ratio of the traction force $F_{\mathrm{tr}}$ and the radial load $F_{\mathrm{r}}(2)$.

$$
\begin{aligned}
& F_{\text {tr }}=\frac{T}{r_{1}} \\
& \mu_{\text {din }}=\frac{F_{\text {tr }}}{F_{\mathrm{r}}}
\end{aligned}
$$

In order to determine the margins of the application, a number of trial runs were conducted varying the rotation frequency and the load, and the highest temperatures achieved were measured. Based on the obtained data, parameters for the experiment were selected for the three combinations of the rotation frequency and the load with lubrication, and one for the dry contact (Tab. 3). In all the cases of lubricated contact the same selected oil was used.

Table 3 Parameters for the load, the rotation frequency and the

\begin{tabular}{|c|c|c|c|c|}
\hline & Run 1 & Run 2 & Run 3 & Run 4 \\
\hline & \multicolumn{3}{|c|}{ Lubricated } & Dry \\
\hline Load $F_{\mathrm{r}} / \mathrm{N}$ & 60 & 130 & 210 & 28 \\
\hline$n / \min ^{-1}$ & 848,8 & 424,5 & 340 & 593 \\
\hline Sliding velocity $v / \mathrm{m} / \mathrm{s}$ & 2 & 1 & 0,8 & 1,4 \\
\hline
\end{tabular}
corresponding sliding velocity

The actual experiment is conducted for 4 different pairs of disc and cube samples made of the selected material. For each pair, three consecutive runs are planned, each lasting 3 hours, i.e. 9 hours in total. If there is no seizure, the sliding path, calculated from the data in Tab. 3, for the Run 1 is $64,8 \mathrm{~km}$, for the Run $232,4 \mathrm{~km}$, for the Run $325,9 \mathrm{~km}$, and for the Run $445,3 \mathrm{~km}$. In all the cases of lubricated contact, before the start of each run, the cylindrical surface of the disc is wiped with a small piece of cloth soaked in the selected lubricating oil. After that, a one minute unloaded run is performed in order to achieve uniform oil distribution between the disc and the cube. After each complete test, the surface roughness of the samples is measured again to be compared with the roughness data measured before the testing.

\subsection{Theory-based calculated values}

To determine the pressure between the samples, the area of the contact has to be known. The Hertz theory is used for the pressure calculation $p$ (3), while Eqs. (4) and (5) are used for the determination of the equivalent elasticity modulus $E_{\mathrm{e}}$ and the contact area half width $a$. The results for the selected parameters are shown in Tab. 4. Since the pairs of samples are made of the same material and have the same dimensions, the only variable parameter in Eqs. (3) $\div(5)$ is the load. Therefore, the pressure $p$ and contact half with $a$ increase width the load $F_{\text {r. }}$.

$$
\begin{aligned}
& p=\sqrt{\frac{F_{\mathrm{r}} \cdot E_{\mathrm{e}}}{2 \cdot \pi \cdot r_{1} \cdot B}} \\
& E_{\mathrm{e}}=\frac{1}{2}\left[\frac{1-v_{1}}{E_{1}}-\frac{1-v_{2}}{E_{2}}\right] \\
& a=\sqrt{\frac{8 \cdot F_{r} \cdot r_{1}}{\pi \cdot E_{\mathrm{e}} \cdot B}}
\end{aligned}
$$

Where: $r_{1}$ is the disc radius $(\mathrm{mm}) ; B$ is the sample width $(\mathrm{mm}) ; E$ is Elasticity modulus of each sample $(\mathrm{MPa}) ; v$ is the Poisson coefficient of each sample 


\section{Results and discussion}

Results of the measurement and calculation of the coefficient of friction for each discrete measuring point are shown in Figs. $3 \div 6$. For the first three runs (Tab. 3, Figs. $3 \div 5$ ) no temperature-induced scuffing occurred. The second run (Fig. 4) was prematurely stopped after 6 hours due to the unexpected system malfunction. The fourth run (dry contact) lasted until only $0,93 \mathrm{~km}$ out of $45,3 \mathrm{~km}$ calculated from the initial parameters (Fig. 6).

Table 4 Pressure and contact half width data for Run 1, Run 2, and Run3

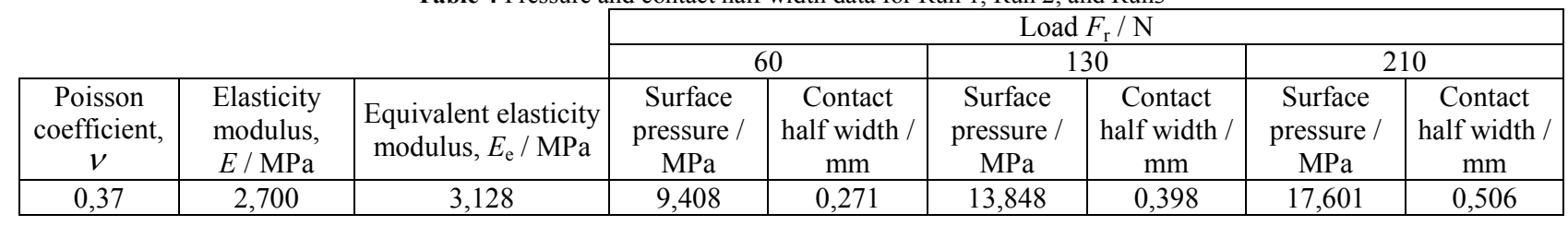

Comparing the temperatures and the coefficients of friction in the diagrams in Figs. $3 \div 5$, the running-in period is visible although it depends on the load. The highest measured temperatures are at $210 \mathrm{~N}$, while those at $60 \mathrm{~N}$, both the average and the discrete, are lower in the whole period of testing. In addition, more variations in the values occur at $210 \mathrm{~N}$, which can be explained by the number of cycles needed to complete the running-in and to achieve a steady operation. This transition occurs earlier in the case of lower load, which can clearly be seen by comparing the second run periods (Figs. 3 and 5). As a consequence of the running-in, the glass transition temperature of the material (about $82^{\circ} \mathrm{C}$ ) has been exceeded in each run, which might lead to a change in roughness. The data on surface roughness before and after the experiment for the first three runs are shown in Tab. 5. The wear of the cube samples is shown in Fig. 7. As expected, the imprint for Run1 is the smallest and it is getting bigger as the load rises. The biggest imprint is in the case of dry run (Fig. 7d) which suffered from seizure.

The analysis of the Figs. $3 \div 5$ has shown that each successful run had a transitions phase whose duration corresponds to the load. At the end, each successful run has entered the steady operating state, while the surface roughness has decreased compared to the initial state. It can be concluded that it is important to achieve the convergence of the contact temperature regarding the load and the surface roughness and thus the coefficient of friction.

Table 5 Surface roughness, Ra, before and after the test for Run 1, Run 2 , and Run 3

\begin{tabular}{|l|c|c|c|}
\cline { 2 - 4 } \multicolumn{1}{c|}{} & \multicolumn{3}{c|}{ Surface roughness, $R \mathrm{a} / \mu \mathrm{m}$} \\
\cline { 2 - 4 } \multicolumn{1}{c|}{} & Run 1 & Run 2 & Run 3 \\
\hline Before & 1,37 & 1,54 & 1,22 \\
\hline After & 1,17 & 1,33 & 0,94 \\
\hline
\end{tabular}

If the temperature does not tend to rise significantly above $90{ }^{\circ} \mathrm{C}$, the mechanical properties of the material will not deteriorate rapidly, and the pair of samples will achieve a steady state of operation eventually. This can be supported by the fact that the maximum temperature, $T_{\text {IRmax }}$ (Figs. $3 \div 5$ ), occurs only once at the beginning of each of the first three tests and does not reoccur downstream. Because the service range of the oil that was used is wider than the temperatures achieved during the operation, a steady lubricating film can be assumed. On the other hand, in the case of dry contact (Fig. 6), due to the lack of lubricant, the initial value of the coefficient of friction is at least 10 times higher compared to the other tested cases, and the contact temperature rises rapidly in a rather short period of time leading to seizure.

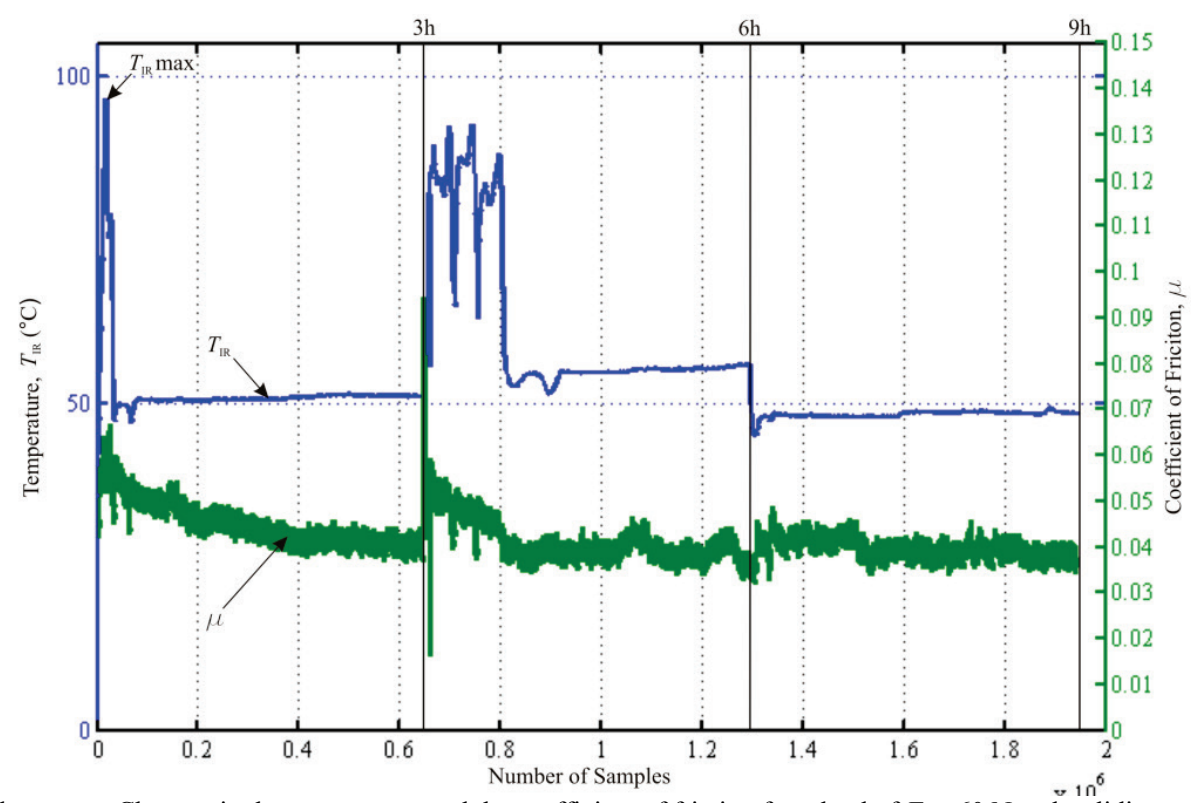

Figure 3 Lubricated contact - Changes in the temperature and the coefficient of friction for a load of $F_{\mathrm{r}}=60 \mathrm{~N}$ and a sliding velocity of $v=2 \mathrm{~m} / \mathrm{s}$ (a sliding path of $64,8 \mathrm{~km})$ 


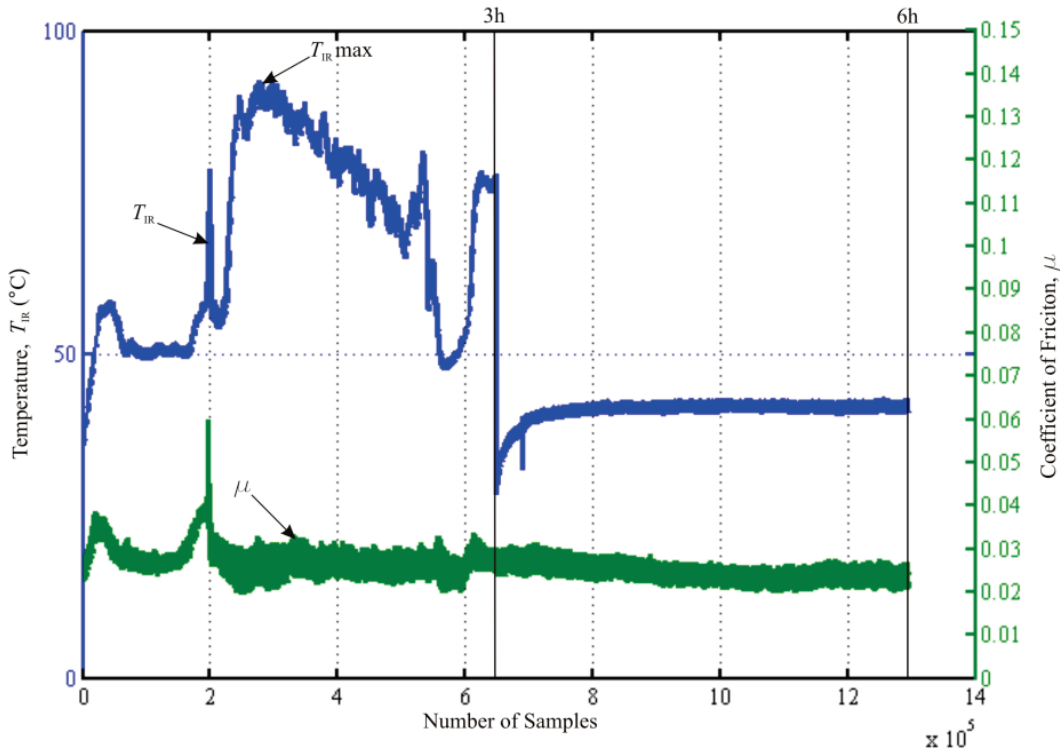

Figure 4 Lubricated contact - Changes in the temperature and the coefficient of friction for a load of $F_{\mathrm{r}}=130 \mathrm{~N}$ and a sliding velocity of $v=1 \mathrm{~m} / \mathrm{s}$ (a sliding path of $21,6 \mathrm{~km})$

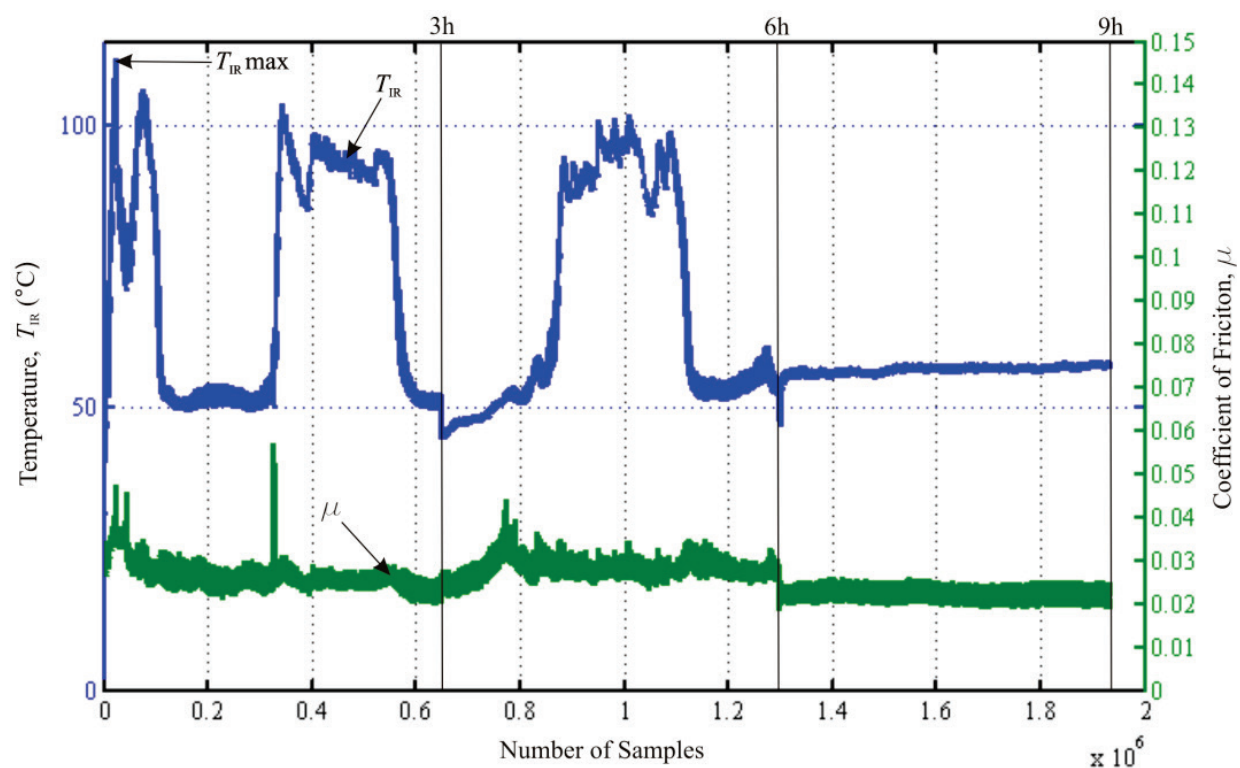

Figure 5 Lubricated contact - Changes in the temperature and the coefficient of friction for a load of $F_{\mathrm{r}}=210 \mathrm{~N}$ and a sliding velocity of $v=0,8 \mathrm{~m} / \mathrm{s}$ (a sliding path of $25,9 \mathrm{~km})$

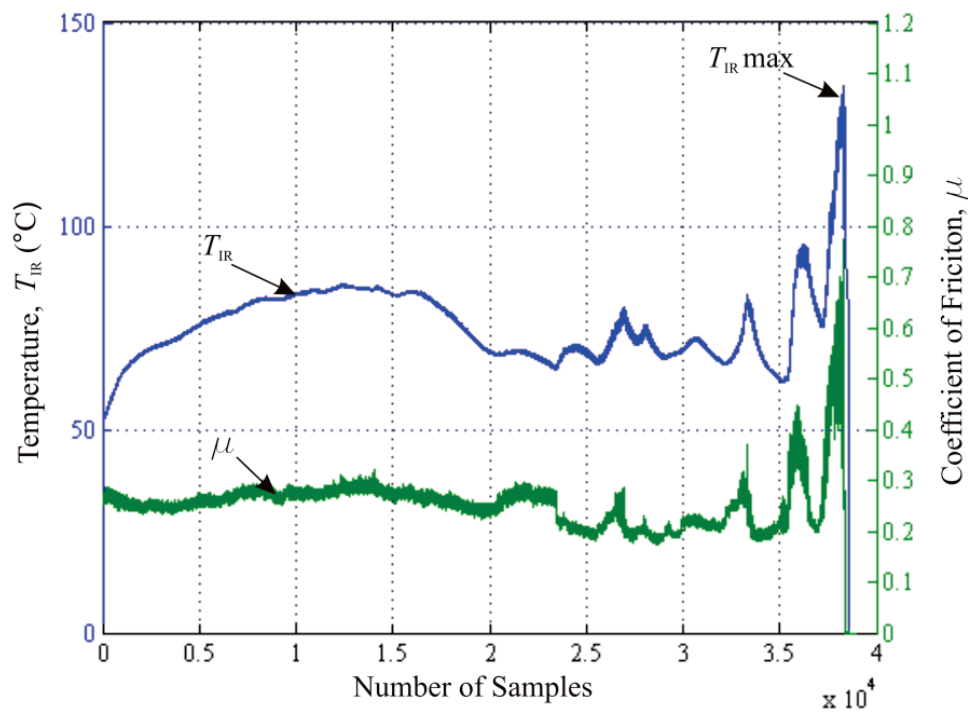

Figure 6 Dry contact - Change in the temperature and the coefficient of friction for a load of $F_{\mathrm{r}}=28 \mathrm{~N}$ and a sliding velocity of $v=1,4 \mathrm{~m} / \mathrm{s}$ (a sliding path $0,93 \mathrm{~km})$ 


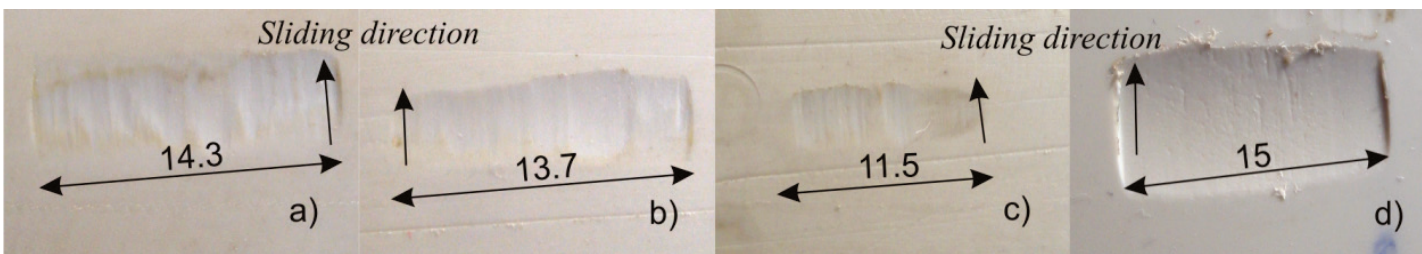

Figure 7 Damage on the surface of the cube samples for: a) $60 \mathrm{~N}, 2 \mathrm{~m} / \mathrm{s}$, b) $130 \mathrm{~N}, 1 \mathrm{~m} / \mathrm{s}, \mathrm{c}) 210 \mathrm{~N}, 0,8 \mathrm{~m} / \mathrm{s}, \mathrm{d}) 28 \mathrm{~N}, 1,4 \mathrm{~m} / \mathrm{s}$ (dry contact)

Coefficient of friction plotted against contact pressure for three different sliding speeds is shown in Fig. 8 (the circles represent corresponding discrete values and the curve represents the $3^{\text {rd }}$ order polynomial trend line). It may be seen that the highest value of the average coefficient of friction of 0,04 is achieved for the Run 1 at a sliding speed of $2 \mathrm{~m} / \mathrm{s}$ and contact pressure of 9,4 MPa. Compared to that, the average coefficient of friction is reduced to 0,025 for the Run 2 with a lower sliding speed of $1 \mathrm{~m} / \mathrm{s}$ and higher contact pressure of 13,8 MPa. A further decrease in the sliding speed and an increase in the contact pressure do not seem to have a significant impact on the average value of the coefficient of friction.

In the temperature-pressure diagram (Fig. 9) one can see that the average temperature in the contact constantly rises with the increase in the contact pressure and the decrease in the sliding speed. Perhaps the most interesting part in the diagram is the predicted deflection of the maximum temperature curve which occurs in a pressure range of $11 \mathrm{MPa}$ to $12 \mathrm{MPa}$. The minimum temperature would be expected in the range which corresponds to the minimum coefficient of friction, which clearly is not the case.

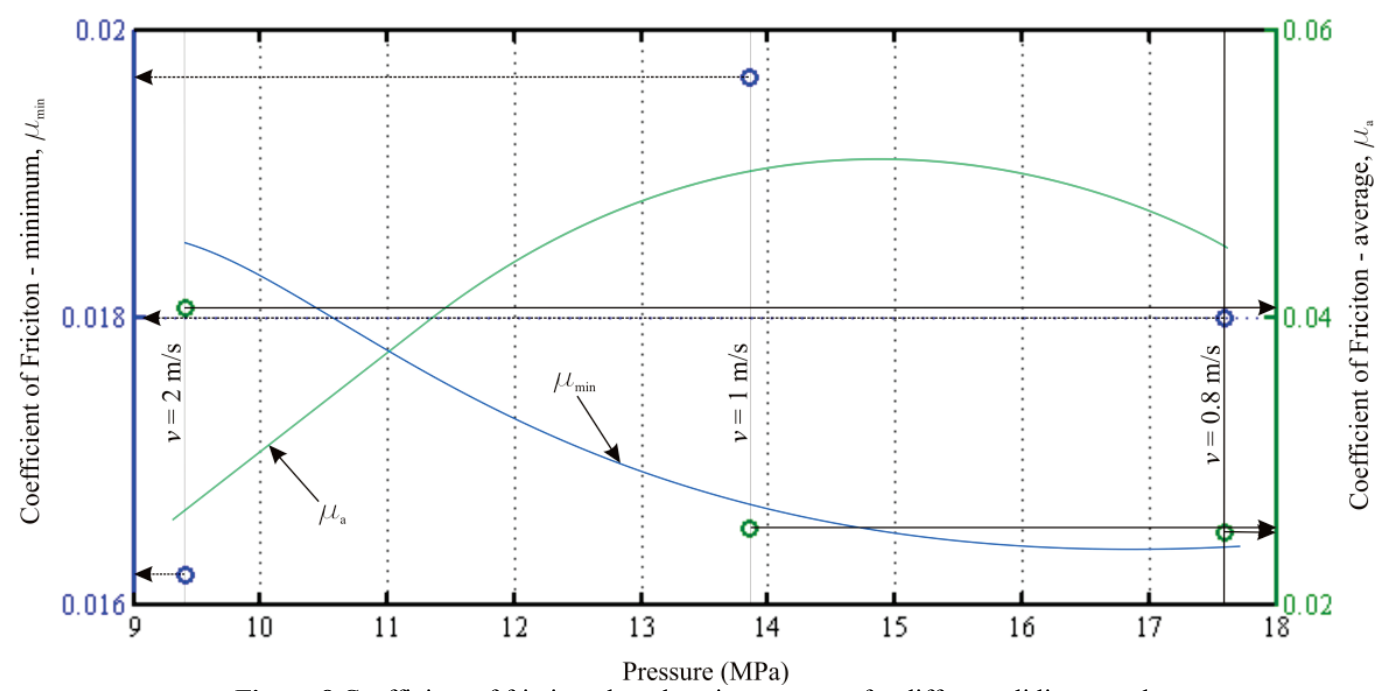

Figure 8 Coefficient of friction plotted against pressure for different sliding speeds

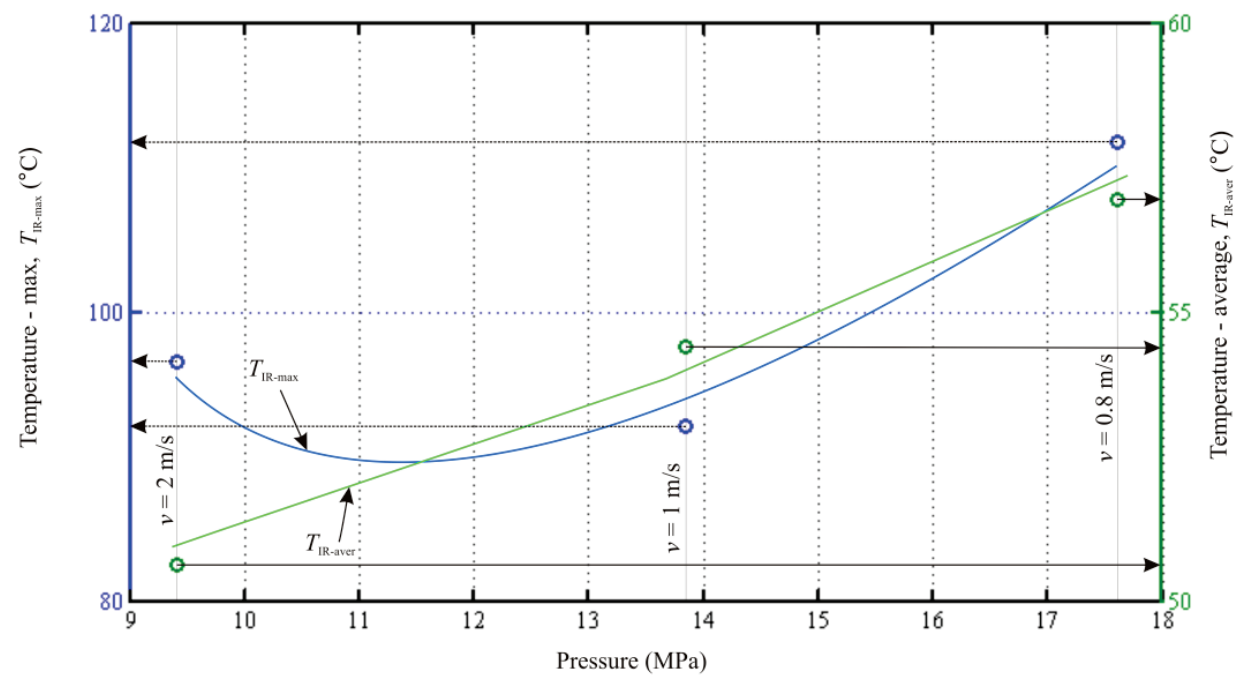

Figure 9 Contact temperature plotted against pressure for different sliding speeds

\section{Conclusion}

The test results show that it is possible to classify the load carrying capacity of samples made of PET according to the temperature measured in the vicinity of the outlet zone of the contact. It has been shown that the load carrying capacity of PET strongly depends on the presence of the lubricant and that even a smallest amount of the lubricant may be sufficient for a positive change in the performance. The results obtained for the coefficient 
of friction in dependence on the sliding speed follow the vertically mirrored Stribecks curve (the sliding speed increases to the left) for the mixed lubrication regime and moderate pressures. More extensive research using parameter variations should be conducted in order to create temperature-pressure-sliding speed diagrams to be used for the predetermination of the working points for various applications of PET. The last, but not the least, the test results indicate that the load, the sliding speed, the lubricating film stability, the glass-transition phase duration and the temperature of the contact might be interrelated. By comparing the results for the three tested pairs of samples one can see that the running-in process takes longer to complete if the load is higher. In order to test this assumption further research needs to be done.

\section{References}

[1] Lancaster, J. K. Dry bearings: a survey of materials and factors affecting their performance. // Tribology. 6, (1973), pp. 219-251. DOI: 10.1016/0041-2678(73)90172-3

[2] Lancaster, J. K. Estimation of the limiting PV relationships for thermoplastic bearing materials. // Tribology. 4, 2(1971), pp. 82-86. DOI: 10.1016/0041-2678(71)90136-9

[3] Jia, Bin Bin; Tong-Sheng, Li; Xu-Jun, Liu; Pei-Hong Cong. Tribological behaviors of several polymer-polymer sliding combinations under dry friction and oil-lubricated conditions // Wear. 262, (2007), pp. 1353-1359. DOI: 10.1016/j.wear.2007.01.011

[4] Zunda, A.; Padgurskas. J.; Vytenis, J.; Kreivaitis. R.: Wear Resistance of Industrial Polymers under Lubrication with Oils // Scientific Journal of Riga Technical University. 21, (2010), pp. 21-25.

[5] Nguyen, T. D.; Nguyen, T. D.; Sukumaran, J.; De Pauw, J.; De Baets, P. Tribological behaviour of polymer bearings under dry and water lubrication. // Ghent University, Laboratory Soete, Belgium.

[6] Sukumaran, J; Rodriguez, V.; De Baets P.; Perez, Y.; Ando, M.; Dhieb, H.; Neis, P. A review on water lubrication of polymers // International Journal Sustainable Construction \& Design. 3, 2(2013), pp. 144-149.

[7] Chen, Beibei; Wang, Jianzhang; Yan, Fengyuan: Friction and Wear Behaviors of Several Polymers Sliding Against GCr15 and 316 Steel under the Lubrication of Sea Water. // Tribol Lett. (2011), pp. 17-25. DOI: 10.1007/s11249-0109743-9

[8] Briscoe, B. J.; Sinha, S. K. Wear of polymers. // J Engineering Tribology, Special issue paper. 216, 2002), pp. 401-413. DOI: $10.1243 / 135065002762355325$

[9] Mens, J. W. M.; de Gee, A. W. J. Friction and wear behaviour of 18 polymers in contact with steel in environments of air and water. // Wear, 149, 1-2(1991), pp. 255-268. DOI: 10.1016/0043-1648(91)90378-8

[10] Šercer, M.; Križan, B.; Basan, R. Konstuiranje polimernih proizvoda, Sveučilište u Zagrebu, Fakultet strojarstva i brodogradnje, 2009.

[11] Čatić, I. Proizvodnja polimernih tvorevina, DPG, Zagreb, 1990.

[12] Gruender, M. High-PV Wear Study of Six High Performance Wear Grade Engineering Plastics. // PBI Performance Products, 2012.

[13] Witold, Brostow. Tribology of polymers and polymerbased composites. // Journal of Materials Education. 32, (2010), pp. 273-290.

[14] Hammerschmidt, J. A.; Gladfelter, W. L.; Haugstad, G. 14. Probing Polymer Viscoelastic Relaxations with Temperature-Controlled Friction Force Microscopy. //
Macromolecules. 32, (1999), pp. 3360-3367. DOI: $10.1021 / \mathrm{ma} 981966 \mathrm{~m}$

[15] Opalic, M.; Domitran, Z.; Katana, B. Comparison of antifriction properties of polymer composites and bronze. // Tehnicki vjesnik - Techinical Gazette. 21, 5(2014), pp. 1089-1095.

[16] Tevruz, T. Tribological behaviours of carbon filled polytetrafluoroethylene PTFE dry journal bearings // Wear. 221, (1998), pp. 61-68. DOI: 10.1016/S0043-1648(98)00258-0

[17] Rowe, K. G.; Bennett, A. I.; Krick, B. A.; Sawyer, W. G. In situ thermal measurements of sliding contacts. // Tribology International. 62, (2013), pp. 208-214. DOI: 10.1016/j.triboint.2013.02.028

[18] Tzanakis, I.; Hadfield, M.; Stolarski, T. A.: Experimental and analytical thermal study of PTFE composite sliding against high carbon steel as a function of the surface roughness, sliding velocity and applied load. // Wear. 303, (2013), pp. 154-168. DOI: 10.1016/j.wear.2013.02.011

[19] Guha, D.; Roy Chowdhuri, S. K. The effect of surface roughness on the temperature at the contact between sliding bodies. // Wear. 197, (1996), pp. 63-73. DOI: 10.1016/00431648(95)06833-3

[20] Suttera, G.; Ranc, N. Flash temperature measurement during dry friction process at high sliding speed // Wear 268, (2010), pp. 1237-1242. DOI: 10.1016/j.wear.2010.01.019

\section{Authors' addresses}

Zoran Domitran, Dr. Sc.

Fakultet strojarstva i brodogradnje

Ivana Lučića 5, 10000 Zagreb, Croatia

E-mail: zoran.domitran@fsb.hr

Dragan Žeželj, Dr. Sc.

Fakultet strojarstva i brodogradnje

Ivana Lučića 5, 10000 Zagreb, Croatia

E-mail: dragan.zezelj@fssb.hr

Branko Katana, mag. ing. mech

branko.katana2@gmail.com 